\title{
Article
}

\section{Tourists at the seaside: Exploring the spiritual dimension}

Jarratt, David and Sharpley, Richard Anthony john

Available at http://clok.uclan.ac.uk/16861/

Jarratt, David ORCID: 0000-0002-7244-428X and Sharpley, Richard Anthony john ORCID: 0000-0002-2135-3206 (2017) Tourists at the seaside: Exploring the spiritual dimension. Tourist Studies, 17 (4). pp. 349-368. ISSN 1468-7976

It is advisable to refer to the publisher's version if you intend to cite from the work. http://dx.doi.org/10.1177/1468797616687560

For more information about UCLan's research in this area go to

http://www.uclan.ac.uk/researchgroups/ and search for < name of research Group>.

For information about Research generally at UCLan please go to http://www.uclan.ac.uk/research/

All outputs in CLoK are protected by Intellectual Property Rights law, including Copyright law. Copyright, IPR and Moral Rights for the works on this site are retained by the individual authors and/or other copyright owners. Terms and conditions for use of this material are defined in the policies page.

\section{CLoK}

Central Lancashire online Knowledge www.clok.uclan.ac.uk

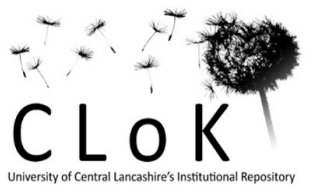




\title{
Tourists at the seaside: exploring the spiritual dimension.
}

By Dr David Jarratt and Professor Richard Sharpley.

\begin{abstract}
Contemporary tourism is considered by many to embrace a spiritual dimension. That is, in increasingly secular modern societies, many forms of tourism represent a sacred journey that has the potential to fulfil the contemporary tourist's spiritual needs. However, relatively few attempts have been made to explore this phenomenon, in particular in the context of one of the most popular tourism settings, namely, the seaside. This paper addresses this gap in the literature. Drawing on research in Morecambe, a traditional seaside resort in the north-west of England, it seeks to identify the extent to which the seaside environment in general, and the sea in particular, endow the touristic experience of the resort with emotional or spiritual significance. A number of clear themes emerge from the research that point to a spiritual dimension of the seaside experience, including a sense of connection, awesomeness, timelessness and nothingness. Nevertheless, further research in other coastal settings is required to substantiate these findings.
\end{abstract}

\section{Keywords:}

Seaside tourism, Sea, Coast, Spirituality, Morecambe 


\section{Introduction}

It has long been recognised that the secularisation of modern societies may 'conceal the sacralisation of previously profane activities' (Allcock, 1988: 33). In other words, as Durkheim (2008) first suggested, when scientific knowledge and rationality supersede institutionalised religion there remains a need for 'mythological representations' and, as a consequence, societies and individuals seek meaning in experiences and practices beyond traditional, organised religion. According to Allcock (1988: 35), one such modern alternative or 'secular substitute' to religion is tourism. Tourism here refers, in general terms, to leisure tourism and it is not claimed that all forms of tourism are spiritual. Since MacCannell (1976) first proposed that the everyday modern tourist is a secular pilgrim, it has been increasingly argued that not only has leisure time in general become 'a space for the contemplative and the creative, a unity of thought and action' (Vukonić, 1996: 8), but also that tourism in particular has become a sacred or spiritual journey 'functionally and symbolically equivalent to other institutions that humans use to embellish and add meaning to their lives' (Graburn, 1989: 22). In short, it is widely suggested that the phenomenon of tourism embraces a spiritual dimension (Brown, 1998; Olsen, 2006; Sharpley, 2009; Timothy and Olsen, 2006).

Significantly, however, research into this spiritual dimension of tourism remains limited; that is, relatively few attempts have been made to verify empirically the suggestion that individuals seek or experience spiritual fulfilment through tourism. In other words, although a number of studies have, for example, explored the (secular) spiritual dimension of tourist engagement in specific (religious) journeys, such as the Camino de Santiago (Devereux and Carnegie, 2006), of the experience of religious sites (Francis et al., 2008; Sharpley and Sundaram, 2005), of specific settings, such as the countryside 
(Jepson \& Sharpley 2015) and of related experiences including holistic (Smith, 2003) and wellness tourism (Steiner and Reisinger, 2006), few have addressed if and how tourists experience a sense of meaning or spirituality through tourism more generally (but, see Willson, McIntosh and Zahra, 2013).

In particular, the relationship between spirituality and seaside tourism has remained largely unexplored in the literature, a surprising omission given the centrality of the seaside to contemporary tourism worldwide. Not only are seaside resorts, specifically those in the UK, associated with the birth of contemporary mass tourism (Pimlott, 1947; Walton, 1983; Walvin, 1978) but also despite experiencing an extended period of decline during the latter half of the twentieth century as seaside tourism became a global phenomenon (Walton, 2000), the resorts in the UK remain popular. In 2013, for example, 142 million day visits were made to the British seaside (Visit England, 2013).

Almost twenty years ago there was a call to 'deepen our understanding of individuals' lifelong experiences of coasts, and the meanings they attach to them' (Tunstall and Penning-Rowsell, 1998: 331), but progress has been inconsistent. This is not to say that the significance or meaning of seaside resort tourism experiences has not benefitted from academic scrutiny; the carnivalesque has long been considered as a fundamental element of the resort experience (Chapman and Light, 2014; Webb, 2005) whilst the seaside as a liminal space is a popular and enduring theme (for example, Gilchrist, Carter and Burdsey, 2014; Preston-Whyte, 2004; Shields, 1991). Furthermore, the therapeutic aspects of the coast have also been considered whilst recently psychologists have investigated the function of blue space (aquatic environments) in terms of wellbeing (see Bell et al., 2015; White et al, 2010; White et al, 2013). In particular, Jarratt $(2015 a, b)$ has considered visitors' reactions to the seaside environment, suggesting they experience a seaside- 
specific sense of place, or seasideness, that embraces a variety of elements notably nostalgia and wellness. Nevertheless, with the partial exception of Jarratt's work, no attempts have been made to consider the extent to which the defining element of a seaside resort, namely the sea, may influence or underpin tourists' spiritual experience of the seaside.

The purpose of this paper, then, is to address this gap in the literature. Specifically, it considers the outcomes of a study which sought to identify in general whether the experience of tourists to Morecambe, a once popular and more recently resurgent traditional seaside resort in the north-west of England (Bingham, 1990; Trotman, 2007), embraces a deeper spiritual or transcendental dimension and, in particular, the significance of the sea - or what may be referred to as the resort's 'blue space' (Völker and Kistemann 2011) - to that experience. In so doing, it not only contributes to understanding of how tourism may fulfil a role as a secular substitute to religion but also points to the need for further research into tourists' emotional experience of arguably the most popular category of destination: the seaside. First, however, it is important to review briefly the significance of spirituality in contemporary society, its relevance to tourism and the evolving significance of the seaside as a tourism destination to provide a framework for the subsequent research.

\section{Religion, spirituality and tourism}

It is widely recognised that the last 150 years or so have witnessed a 'shift in the sacred landscape' (Heelas and Woodhead, 2005: 2) of western society. More specifically, the modernisation of society has been accompanied by a process of secularisation as evidenced by a decline in the perceived relevance of and adherence to traditional religious institutions and practices (Brierley, 1999; Lambert 2004; Stark, Hamberg and Miller, 2005) whilst, in particular, 
there has been a decrease in the influence and role of the church, an institution that offered stability, cohesion and spiritual guidance to its followers (Wuthnow, 1998). Consequently, it is suggested that contemporary society, arguably set adrift with no moral compass (Houtman and Aupers, 2007), has come to be defined by a search for spirituality; as Brown (1998: 1) puts it, 'The spiritual search has become a dominant feature of late twentieth-century life; a symptom of collective uncertainty'.

This is not to say that the quest for spiritual meaning and fulfilment is a recent phenomenon, for spirituality is fundamental to traditional religious belief in a higher being external to the self (Vukonić, 1996); that is, to be religious is to be spiritual and hence, religion and religious practice has always been an expression of spirituality. It is also not to say that increasing secularisation has resulted in a religious vacuum in society. Indeed, as Heelas and Woodhead (2005) observe, there is evidence of an increasingly widespread desire within society to sustain and nurture spiritual health. In other words, religion is, in a sense, not in decline but taking on a new form; it has become deinstitutionalised (Harvey, 2003) and is manifested in a variety of individualistic and group spiritual practices unencumbered by traditional religious institutions, prescribed theologies and rituals and communal responsibilities. Putting it another way, spirituality may be thought of as a postmodern manifestation of religion, an individualistic search for meaning and harmony and a connection with the world (Pargament, 1999).

Nevertheless, religion and spirituality are not synonymous. Certainly, from a theological perspective the increasing focus on spirituality may be considered evidence of a transformation in or evolution of religious practice, not least because many definitions suggest that spirituality embraces both the individual search for meaning and a belief in a higher / supreme power (Dyson, 
Cobb and Forman 1997; Kale, 2004; Miner-Williams, 2006; Zinnbauer, Pargament and Scott, 1999). However, people may seek or have what they consider to be spiritual experiences without holding religious beliefs or a belief in higher being (Heelas, 1998). For instance, recent research has revealed that, in Britain:

spiritual beliefs are not the preserve of the religious. . a majority of nonreligious people hold spiritual beliefs. This is particularly evident when it comes to non-traditional forms of religious beliefs, where it seems to make very little difference whether someone considers themselves religious or not (Theos, 2013: 25).

Similarly, Hay and Socha (2005) identify the paradox that, despite the alleged secularisation of contemporary society, there is evidence of an increase in reported spiritual experiences. This they put down to the fact that 'spiritual awareness [is] natural and universal within the human species' (Hay and Socha 2005: 607). In other words, as Willson et al. (2013) discuss at length, to be human is to be spiritual; one's spirit is the essence who one is and, inevitably, all humans are engaged purposefully or otherwise in a spiritual quest, a search for meaning.

This suggests that, certainly for the purposes of this paper, a broader conceptualisation of spirituality is required that may include but does not necessitate 'religious' beliefs or a belief in a higher power. Usefully, for example, Heelas and Woodhead (2005) expand on their concept of a shift in the sacred landscape referred to above by suggesting that the more traditional spiritual 'life as' (that is, life lived as an expected, obligated role conforming to a transcendent authority) has been relegated in favour of a 'subjective life' lived in accordance with an individual's inner needs, desires and capabilities - this reflects an increasingly common secular humanism. In this context, 'the term 
"spirituality" is often used to express commitment to a deep truth that is to be found within what belongs to this world' (Heelas and Woodhead, 2005: 6). In a similar vein, Fisher, Francis and Johnson (2000: 135) identify four domains within which harmonious relationships are necessary for the achievement of spiritual well-being: (i) the personal, (ii) the communal, (iii) the environmental and (iv) the transcendental. Thus, spiritual fulfilment may be achieved through one or more of self-identity and esteem, inter-personal relationships, a sense of awe and connectedness with the natural environment and a relationship between the self and a higher thing or being.

This more complex, humanistic perspective on spirituality is of particular relevance here. That is, there has long been an articulation between spirituality and tourism, not least in the context of pilgrimage and other forms of religious tourism (Rinschede, 1992) but, as noted above, tourism has more recently come to be seen as secular, 'this world' substitute for religious practices, a secular sacred journey. As such, participation in tourism offers the opportunity to seek or experience spiritual well-being according to Fisher et al's (2000) domains, not least the environmental domain. Indeed, academic attention has long been paid to the relationship between psychological well-being and the natural environment in general (for example, Burls, 2007; Darker, Larkin and French, 2007; Driver et al., 1996; Kaplan, 1995; Korpela and Hartig, 1996; Montes, 1996) and the potential spiritual benefits from accruing from experiencing specific environments, such as forests and wilderness, in particular (Fredrickson and Anderson, 1999; Heintzman, 2010). It should also be noted that significant attention has been paid to the physical health benefits of natural, green spaces, although this literature is beyond the scope of this paper (for this see Hartig et al., 2014). However, with notable exceptions (for example, Jepson and Sharpley, 2015) few attempts have been made to explore 
the spiritual dimension of the tourist experience of specific types of destination, the seaside being a particular omission.

\section{The significance of the seaside}

As observed above, the development of seaside resorts in nineteenth century Britain heralded the advent of contemporary mass tourism, although initially they remained the preserve of the leisured / upper classes. A visit by the Prince of Wales in 1783, for example, confirmed Brighton as a fashionable destination and, by the end of the 1700s, 'the seaside holiday had become a wellestablished feature of the social calendar' (Walton, 1983: 16). From the mid1800s onwards, however, the resorts attracted a wider market and by the turn of the century were firmly established as popular mass tourism destinations, a position they were to maintain until tourists began to turn their attention to the resorts of the Mediterranean and elsewhere (Walton, 2000).

The rise and decline of the British seaside resort as a built environment is considered at length in the literature (for example, Pimlott 1947; Gale, 2005; Hern, 1967; Shaw and Williams, 1997; Walton, 2000; Walvin, 1978), whilst their cultural significance has also been widely considered (Gilchrist et al., 2014; Shields 1991; Urry and Larsen, 2011). However, surprisingly less attention has been paid to the emotional or spiritual significance of the natural environment of the seaside and, specifically, the sea, particularly within the context of the tourist experience. Nevertheless, from the extant literature it is evident that, over time, that significance has evolved in a manner similar to that of natural land environments. In other words, prior to the Enlightenment both the sea and the coastal margin between it and civilisation were often perceived with distaste and even fear: 'it is along the beach that ocean purges itself and throws up its monsters' (Corbin, 1994: 13). Corbin (1994) argues that Medieval Europeans 
typically considered to the sea be demonic, a symbol of purgatory and something to be feared - reflecting the prevailing Christian ideology of that period. As plagues decimated Europe in the early fourteenth century, exposure to water was seen as the most powerful way to open up the body to infected air and, consequently, a horror of the beach developed from this fear of water (Lencek and Bosker, 1998).

By the seventeenth century, however, not only were the mysteries of the oceans being unlocked by explorers and science but also, following the emergence of natural theology espoused by the neo-Platonists during the Renaissance, attitudes towards the sea and the coast became more positive (Corbin, 1994). The natural world became linked to the spiritual and, in particular, the sea became in religious terms not a symbol of purgatory but of a world reconfigured to God's design; as Corbin (1994: 24) notes, 'the present Earth therefore appeared to be a book written by the creator and intended for man.' Thus, the stage was set for the popularisation of the coast and the sea, in three particular ways. Firstly, the Romantics were instrumental in the transformation of the coast from a place of fear to one of beauty and contemplation; just as wilderness areas were transposed through art and literature into sublime landscapes (Brady, 2003). Coastal tourists were subsequently attracted; literate travellers 'began to appropriate the bundle of Romantic sensations as the frame through which they themselves experienced and described their responses to the sea and beach' (Lencek and Bosker, 1998: 96).

Second, the seaside became associated with health and well-being (Hassan, 2003). In the 1750s the medical profession, most famously Dr Richard Russell, advocated both drinking and swimming in cold seawater - indeed, Corbin (1994: 70) claims that the newly discovered health-giving properties of 
seawater led directly to the 'the invention of the beach' (1994: 70) - whilst subsequently the benefits of 'ozone' in the air would be promoted by doctors (see Pimlott 1947: 105). More recently, natural environments have in general come to be recognised as beneficial to both physical and mental health and well-being. Kaplan (1995), for example, links natural environment experiences both to the management of stress and psychological health and to the promotion of cognitive freedom, the latter suggesting that in natural environments, conscious processing no longer dominates and transcendental states are more likely to occur. More specifically, recent work concludes that positive psychological benefits (calm, refreshment and enjoyment) are most likely to occur in coastal or 'blue space', rather than urban or rural, environments (White et al, 2010; White et al, 2013).

Third, and of most relevance to this paper, the spiritual dimension of the coast and sea has increasingly come to be recognised. Lencek and Bosker (1998: 97), for example, observe that Wordsworth, Keats, Coleridge and Byron all 'sensed in the vast organic entity of the sea the same amalgam of spirit that stirred in the depths of the human soul' whilst Bachelard saw a connection between the immensity and limitlessness of the seas and the depth of inner space within us all. When one looks at both nothing and a hidden world at the same time, one's spirit can no longer remain 'sealed or indivisible' (Bachelard, 1994: 206). More generally, the beach has long been, and continues to be, a place where religion, spirituality and the sea inter-connect:

The symbolism attached to dawn, and the cleansing act of immersion that takes place during religious ceremonies on beaches is probably ages old. These actions seem to induce in believers a feeling of religious passion that imbues the beach with a special meaning. It becomes a liminal space in which normal statuses are temporarily suspended; it becomes a sacred place (Preston-Whyte, 2004: 353). 
In contrast, in a ground-breaking paper, Bull (2006) explores a variety of humanistic spiritual dimensions of a visit to the seaside, from a correspondence between the sea's and life's rhythms to a regression to childhood. However, the extent to which the seaside offers spiritual experiences to tourists remains uncertain, hence the research to which this paper now turns. First, the setting of this research and the seaside experiences which lie at the centre of this paper are considered briefly.

\section{Morecambe and Morecambe Bay}

Morecambe, with a population of 39,000 , is located in the North West of England. The resort developed in the nineteenth century and expanded rapidly in the early twentieth century although in the decades following a post-World War Two boom, decline set in. This once popular resort experienced a dramatic fall in numbers and sustained a loss of attractions, touristic infrastructure and reputation. By the early 1980s, it was very clear that Morecambe's tourism economy had been transformed (Hassan, 2003), the resort becoming associated with range of social-economic problems with deprivation at their core (Bingham 1990). Indeed, many once popular British seaside resorts today suffer significant deprivation relative to other urban centres (Centre for Social Justice, 2013; McVeigh, 2014; Office for National Statistics, 2013). Moreover, working class seaside towns such as Morecambe have for many years been considered unfashionable; as Urry (1997: 103) commented, 'they do not signify good taste'. However, the 1990s saw the start of a partial recovery in Morecambe as parts of the resort and especially the promenade benefitted from regeneration policies and, over the last two decades, visitor numbers have steadily increased (Lancaster City Council, 2011; Trotman, 2007). Even the author of the popular 
Morecambe-inspired book 'Crap Towns', published in 2003, concedes that the resort has much improved in recent years (Jordison, 2012).

Of particular relevance to this paper, the attraction of Morecambe, even in its touristic heyday, lay not only in the town itself but also in access to the seaside environment and, specifically, the visual seascape afforded to tourists. Indeed, now that the once substantial touristic infrastructure has been stripped away and with the significant socio-economic challenges that the resort continues to face nowadays, it is the coastal environment and the views out to sea that principally draw visitors to Morecambe. As discussed shortly, the research revealed that most respondents considered their experience of Morecambe in the context of the coastal environment and seascape, specifically Morecambe Bay which makes up a large part of the view and after which the resort is named.

Morecambe Bay is Britain's largest intertidal area and, with its tides and open spaces, offers a dynamic, dramatic and distinctive vista both out to sea and towards the mountains of the Lake District towards the north-west. To quote William Wordsworth, Morecambe Bay is a great 'plain from where the sea has retired' (cited in Donaldson, 2014). The bay is, perhaps, most famous for its sunsets - indeed, it was this that was traditionally featured in postcards of the resort, offering photographs of the sun setting behind the Lake District mountains across the bay with the sands and waters in the foreground. It was also this feature of Morecambe that gave the resort its motto 'Beauty Surrounds, Health Abounds' (Bingham, 1990: 184) and, as now discussed, potentially influences its spiritual interpretation by contemporary tourists. 


\section{Method}

As discussed above, the aim of the research was to identify the extent to which the experience of tourists to Morecambe embraces a deeper spiritual or transcendental dimension. That is, it set out to explore the potential emotional influence of the seaside environment in general, and the significance of the sea in particular, on the experience of visitors to the resort. In order to achieve this aim, a qualitative approach was adopted. Specifically, semi-structured interviews, each lasting approximately an hour, were conducted with a total of ten tourists visiting Morecambe during the summer period, the purpose being to 'get inside the interviewees head' to reveal the texture of their seaside experiences. As is common in studies that rely on in-depth interviews to reflect a perspective rather than a population, a small number of relatively homogeneous cases were purposively selected (Smith, Flowers and Larkin, 2009).

The ten interviewees were initially identified and selected through data collected during an earlier wider study, undertaken by one of the authors, which took the form of a self-completed questionnaire distributed amongst tourists in Morecambe and which otherwise does not inform this paper. As observed by Gratton and Jones (2004), clear criteria are required to enable the intended purposive screening and the selection of appropriate cases. For the purposes of this research, the following screens were used to select the final ten cases: the visitors in the sample had to be aged 55 to 74 years, live in the North of England and be repeat visitors to the resort. These screens were based around the 'average' visitor to Morecambe in terms of both visiting habits and demographics, as revealed in the results of the aforementioned questionnaire survey and also by earlier research into Morecambe's visitor economy (see Gibson, Crawford and Geddes, 2008) - see Table 1 for details. 
Table 1: Interviewee Details.

\begin{tabular}{|c|c|c|c|c|c|c|c|}
\hline Initials & Sex & Age & $\begin{array}{l}\text { Area of } \\
\text { residence }\end{array}$ & $\begin{array}{l}\text { (Former) } \\
\text { occupation }\end{array}$ & $\begin{array}{l}\text { Employme } \\
\text { nt status }\end{array}$ & $\begin{array}{l}\text { How often } \\
\text { they visit } \\
\text { Morecambe }\end{array}$ & $\begin{array}{l}\text { How long } \\
\text { they have } \\
\text { been } \\
\text { visiting }\end{array}$ \\
\hline D.B. & $\mathrm{M}$ & $\begin{array}{l}55- \\
64\end{array}$ & $\begin{array}{l}\text { Chorley, } \\
\text { Lancashire }\end{array}$ & $\begin{array}{l}\text { Education / } \\
\text { training }\end{array}$ & $\begin{array}{l}\text { Employed } \\
(\mathrm{p} / \mathrm{t})\end{array}$ & $\begin{array}{l}\text { Once a } \\
\text { month }\end{array}$ & 60 years \\
\hline P.K. & $\mathrm{F}$ & $\begin{array}{l}65- \\
74\end{array}$ & $\begin{array}{l}\text { Grange, } \\
\text { Cumbria }\end{array}$ & $\begin{array}{l}\text { Finance } \\
\text { Officer }\end{array}$ & Retired & Rarely & Unknown \\
\hline W.H. & $M$ & $\begin{array}{l}55- \\
64\end{array}$ & $\begin{array}{l}\text { Bilsborrow, } \\
\text { Lancashire }\end{array}$ & $\begin{array}{l}\text { Kitchen } \\
\text { Porter }\end{array}$ & Employed & $\begin{array}{l}\text { Once a } \\
\text { month }\end{array}$ & 45 years \\
\hline G.D. & $M$ & $\begin{array}{l}65- \\
74\end{array}$ & $\begin{array}{l}\text { Clitheroe, } \\
\text { Lancashire }\end{array}$ & Teacher & Retired & $\begin{array}{l}\text { Several } \\
\text { times per } \\
\text { year }\end{array}$ & 10 years \\
\hline T.M. & $\mathrm{M}$ & $\begin{array}{l}55- \\
64\end{array}$ & $\begin{array}{l}\text { Garstang, } \\
\text { Lancashire }\end{array}$ & Chef & Retired & $\begin{array}{l}\text { Once a } \\
\text { month }\end{array}$ & 35 years \\
\hline A.D. & $\mathrm{F}$ & $\begin{array}{l}65- \\
74\end{array}$ & $\begin{array}{l}\text { Barnsley, } \\
\text { S. Yorkshire }\end{array}$ & $\begin{array}{l}\text { Nursery } \\
\text { Nurse }\end{array}$ & Retired & Rarely & 12 years \\
\hline W.S. & $\mathrm{M}$ & $\begin{array}{l}65- \\
74\end{array}$ & $\begin{array}{l}\text { Northwich, } \\
\text { Cheshire }\end{array}$ & Engineer & Retired & Rarely & $\begin{array}{l}\text { Since } \\
\text { childhood }\end{array}$ \\
\hline P.P. & $\mathrm{F}$ & $\begin{array}{l}65- \\
74\end{array}$ & $\begin{array}{l}\text { Penwortham, } \\
\text { Lancashire }\end{array}$ & $\begin{array}{l}\text { Council } \\
\text { employee }\end{array}$ & Retired & Rarely & $\begin{array}{l}\text { Since } \\
\text { Childhood }\end{array}$ \\
\hline P.S. & $\mathrm{F}$ & $\begin{array}{l}65- \\
74\end{array}$ & $\begin{array}{l}\text { Preston, } \\
\text { Lancashire }\end{array}$ & Housewife & Retired & $\begin{array}{l}\text { Once a year } \\
\text { or so }\end{array}$ & 45 years \\
\hline B.J. & $\mathrm{F}$ & $\begin{array}{l}65- \\
74\end{array}$ & $\begin{array}{l}\text { Allithwaite, } \\
\text { Cumbria }\end{array}$ & $\begin{array}{l}\text { Primary } \\
\text { Teacher }\end{array}$ & Retired & $\begin{array}{l}\text { Several } \\
\text { times per } \\
\text { year }\end{array}$ & 30 years \\
\hline
\end{tabular}

To encourage the interviewees to discuss their experiences of Morecambe openly and honestly, perhaps addressing issues and emotions not normally considered, prior to the interviews attempts were made to put interviewees at ease and to build their confidence. For example, interviewees were given the opportunity to decide themselves where the interview should take place. As a consequence, seven of the interviews were conducted in the interviewee's primary residences (see Table 1) details of which were collected in the aforementioned earlier study, whilst the remainder took place in a familiar 'neutral' setting (a café or pub) chosen by the interviewee. During the course of the interviews, respondents were asked to discuss their experiences of visiting 
Morecambe. The questions were open, neutral and non-leading though, given the focus of the research, sought to elicit the emotional meaning or significance (and the source of that meaning) on the part of interviewees. All interviews were digitally recorded and fully transcribed.

Analysis was conducted manually to allow familiarity with the transcriptions and to avoid the 'mechanistic' approach which is sometimes attributed to computer analysis (Gratton and Jones, 2004: 225). The stages of analysis in this study were influenced by the work of Smith, Flowers and Larkin (2009) and are outlined here. The first stage in the analysis process was rereading each transcript, as well as listening to the recordings again. Next came the initial noting; this second stage could be seen as a free textual analysis, as notes were made on anything of interest and significance to the seaside experience of the interviewees. The following stage was concerned with themes emerging from both the original transcription and the initial notes, the aim being to turn the original transcript and notes into a concise statement and reflect an understanding. Here, the researcher was only concerned with one individual case and the themes therein. These themes were grouped through a process of abstraction; that is, similar themes were brought together within an appropriately titled cluster. Only when this process was completed for one case did the researcher move onto the next case. Each case was treated individually in its own right, thus allowing new themes to emerge; in other words, an idiographic approach was adopted. Once all the individual case analyses were completed, patterns across all interviews were then considered and a crosscase table of themes was produced which informs the structure of the discussion below. These general themes that comprise the following subtitles/subsections are supported by the voices of the interviewees themselves; for clarity, their words are presented in italics and, for (anonymous) 
identification their initials are indicated after each quote. The link between the emergent themes across cases and the spoken word is not broken; this process follows the principles of the inductive approach, moving from the particular to the general.

\section{Results and discussion}

The wider seaside experience

Prior to considering the specific emotional or spiritual dimensions of their experiences as revealed by the interviewees, it is first appropriate to contextualise these by outlining briefly the physical nature of the wider visitor experience in Morecambe. All of the interviewees visited the resort because of the coastal strip; that is, to experience the promenade area, the beach and the views across the bay and out to the open sea. Indeed, all of the interviewees indicated that, during their visits, they spent time on / walking along the promenade. This reflects the behaviour of contemporary tourists in Morecambe more generally; according to the questionnaire survey referred to above amongst 200 visitors in Morecambe, the great majority of respondents (77\%) reported that at some stage during their visit they walked along the promenade, making it by far the most popular leisure activity amongst visitors to the resort.

From their responses, it was also clearly evident that the interviewees visited Morecambe because of relatively easy access to what they considered to be a much valued seaside environment. They were also keenly aware that Morecambe faces a number of challenges with respect to the town's reputation and deprivation. Nevertheless, they were happy to visit the regenerated coastal area despite the fact that there remain many less attractive parts of the resort; indeed, they saw the resort as divided between an attractive coastal area and a more problematic hinterland. Thus, it would appear the coastal zone and 
seascape is of paramount importance to these visitors and, unsurprisingly perhaps, the principle themes to emerge from this research reflect this significance of the coast and the sea. Putting it another way, given the challenges the town continues to face, it may at first appear incongruous that there exists a clear 'spiritual' element to the visitor experience of Morecambe. However, the tourist experience of Morecambe, identified here, is primarily an experience of the coast and the sea rather than of something specific to the built resort:

I mean, to me the seaside is, as the name implies, it's the seaside. And I don't think it matters too much where you are, if you're at the seaside you're at the seaside [W.S.]

Let us now consider what visiting the coastal environment means to these respondents, with a particular focus on the potentially spiritual aspects of their experience. The following discussion is structured around distinctive themes emerging from the research.

\section{A place of beauty and reflection}

During the interviews, it was the view out to sea or across the bay that was referred to or described most frequently and in much more emotive terms than any other element of the seaside experience. Moreover, the interviewees frequently expressed a sense of attachment to the seascape itself, as demonstrated by one who explained that:

...you look across that bay, particularly on a summer's evening when the sun's going down, and, and it's over the bay and there's such beautiful sunsets and beautiful views that you can't help but, but be, be attracted to it and can't help but be affected by it. And I think this is what sort of happened over the years - I think it's turned much more into that, into the, the serenity and, and the, the...the love of that view... [D.B.] 
Many interviewees referred to Morecambe Bay as 'picturesque', 'beautiful' and even 'sublime', words that have been associated with attractive landscapes throughout the industrial and post-industrial phases of Britain's history (Aitchison, MacLeod and Shaw, 2002). Descriptions in the interviews of looking out at the view and experiencing the seaside were often the pre-cursors to respondents' observations regarding their lives, their place in the world and spirituality. In other words, the interviewees displayed a feeling of expanded thought through experiencing what they considered to be 'nature'. The seashore and the sea have, as noted earlier, long been associated with deep thought and, certainly from the evidence of this research, this still appears to be the case. Specifically, the respondents considered the seashore to be a place of contemplation and even meditation; a place where one can think clearly and deeply. The quietness, open views and serenity are seaside characteristics that lend themselves to such thought or contemplation, and perhaps set it apart from other environments:

Just a changing world, and you can still look out to sea, and go to your own personal favourite spot and just look out and think... [W.H.]

I visit at the moment. I think it's because it's, it's quiet and it's, it's that view across the bay, the sort of serenity, a pleasurable thing to do, to just look out there and, and you know, just lose yourself in, in the whole thing. [D.B.]

\section{Making a connection}

As this paper has already discussed, a feeling of connection or re-connection to the environment in general can be considered spiritual (Fisher et al., 2000; 
Heelas and Woodhead, 2005). During the interviews, it became evident that the respondents considered their seaside visits and, specifically, looking out to sea as a meaningful experience. More specifically, some suggested that visiting the seaside stimulates a sense of connection or re-connection with the natural world. This broadly reflects Schopenhauer's writings on the sublime (Schopenhauer, 2010) and can be considered a spiritual experience in the broadest sense. Indeed, as discussed in the preceding review of literature (Heelas and Woodhead, 2005), spiritual is an umbrella term which, in these interviews, was revealed as being most closely associated with a secular notion involving (re)connection with the natural world through appreciating its beauty, complexity, scale and timelessness.

Importantly, the interviewees indicated that they felt a bond or connection with the sea, which was spiritual in nature and, and they described as such 'Well I think it's spiritual really'. [A.D.]

This connection was considered spiritual in the sense that that the seaside experience was perceived by the interviewees to be an opportunity to re-connect with something bigger and more permanent than themselves. Interacting with the seaside environment was seen to be much more than simply appreciating nature; rather, it is linked to people's relationship with it and their place in the world. Interestingly, one interviewee referred to the beliefs of Native Americans to explain how she felt about this connection with nature, very much chiming with Gayton's (1994) observation that Western societies do does not possess a sufficient vocabulary to describe their connection with nature and so rely on other cultures, such as native Americans, to express this:

It's sort of part of our whole being isn't it, you know, it's like a brother or a sister or a, you know, it's just part of us. [A.D.] 
Another interviewee outlined his desire to re-connect with the sea in the clearest and most physical of ways, swimming, and went on to explain our relationship with the ocean:

...you kind of want to get back in the sea. I mean if I get the chance even now, you can't do it in this country, there's nothing I like better than swimming in the sea... And I think, I think what we were just saying, it is that feeling that, you know, we belong to the sea, sort of thing. [W.S.]

In the first line, he refers to his desire to return to the sea whilst, similarly, his use of the word 'belong' at the end of this quotations infers more than just some generic connection but humanity's evolutionary link to the sea, the harbinger of life. This urge to re-connect with the sea is therefore linked to the very distant past. Earlier in the interview, the same respondent (W.S.) also referred to the sea as 'primeval', reflecting a theme that emerged in a number of interviews, namely, the apparently timeless nature of the sea and its relevance to the interviewees' view of our collective past.

\section{Timelessness}

The seemingly timeless has the ability to put our own lives, with their relatively short spans, into perspective. This was indicated most strikingly by one interviewee (P.S.) who, since this research was conducted, has sadly passed away after a long struggle with illness. She indicated that her visits to what she considered a timeless coast had very much helped her to put things into perspective and to remain positive.

.... when we're not here they'll still be...the tide will ebb and it'll flow. [P.S.] 
This perceived timelessness can be considered as a part of the truly sublime (Schopenhauer, 2010). As visitors look out to sea, they see the beautiful and the sublime, a timeless blank canvas without any evidence of the encroachment of mankind. The sea view and liminal zone stand outside of perceptible time, thereby allowing or encouraging a range of emotional reactions, including sublimity. The open views and natural environment possessed properties that encouraged the interviewees to contemplate existence and creation.

Nevertheless, it would be a mistake to assume that a significant number of visitors to the seaside are engaging in a specific quest for meaning through their visits. For example, in their study, Sharpley and Jepson (2011) found that most tourists did not visit the Lake District purposefully or primarily for spiritual fulfillment but nevertheless their visits often embraced this dimension of the experience. Similiarly, seaside visitors enjoy and value this connection with something meaningful that sits outside their everyday experience, and view it as an element of the visit to Morecambe. One interviewee saw this as commonplace and went on to state:

Yeah. I think there probably is something in everyone's soul... looking out to sea, especially at sunset, something like that...Seeing the waves coming in and the sun go down. $\mathrm{Mm}$. [W.H.]

The seaside environment was seen to be natural and to contrast sharply with the frenetic pace of modernity, the pressures of work and the nature of modern life. Nature is often considered a place removed from modern tempos where one can recharge (Carter, 2014). Furthermore, the seemingly timeless and unchanging seaside offered an opportunity to put things in perspective in terms of time, to tune into the rhythm of waves and tides and, essentially, to slow down. The seaside is seen as reassuring; these observations are reflected in the following statements: 
And to be able to look at something that is unchanging, and for all intents and purposes will always be like that, maybe it's a little bit... has a calming effect, you know, to see that something won't change. Mankind's changing so much. [W.H]

...it takes your mind completely away from all our sort of manmade hustle and bustle. It takes you right back to nature really doesn't it? [A.D.]

\section{Awesomeness}

Like timelessness, the awe-inspiring scale of the vistas combined with the perceived power of nature was referred to by respondents as a significant element of the seaside experience. Timelessness, nothingness and awesomeness were described in similar terms and often at the same time. Whilst apparently overlapping concepts in the minds of the visitors, each was specifically mentioned and so they are considered here separately. The interviewees linked the awesome, or awe inspiring, nature of the sea to their place in the world and creation. Furthermore, it was considered an assurance that there is something bigger out there whilst connecting to feelings of peace: ...because I mean when you're in it yourself, you know, you're just like a tiny little speck and a wave and all these huge rollers coming in and different tides and, you know, it does make you feel, you know creation, well to me I just feel it's very peaceful and, you know, sort of quite awesome really. [P.P.]

Here, the role of scale, encouraging a new perspective, becomes clear. The grandeur and dynamic nature of this apparently sublime, timeless and awe inspiring natural environment tap into the imagination and illicit a strong emotional response, which may take more than one form. For one interviewee 
in particular (G.D.), looking out to sea was a powerful experience that reaffirmed his Christian faith. Indeed, he was the only interviewee who referred explicitly to God rather than a seemingly secular spirituality. However, this interviewee was not alone in letting the beautiful external environment affect his internal processes as these issues 'work through' him. He was clearly well read as he correctly refers to natural theology at this point; God is revealed to him through such experiences:

So, in that situation I do think about God and I think about creation and I think about beauty and so on. So, it's called natural theology. So, I, I look at these things, and, you know, there are all kinds of theological things begin to, to work through me. [G.D.]

\section{Nothingness}

On Margate Sands.

I can connect

Nothing with nothing. (Eliot, 1922: 300)

The Cumbrian author and poet, Norman Nicholson, associates Morecambe Bay with, 'an experience of forgetfulness, of oblivion, of detachment from the everyday' (Nicholson, 1955: 76). This concurs with the views of the interviewees who also saw this experience as a connection to something bigger than us on one hand, but also as a reconnection with a more natural state of being and a temporary loss of individual identity on the other. Out there offers an escape from ourselves into a consciousness that just is. One interviewee had such a spiritual experience but expressed herself very eloquently. She referred to the 'nothingness' of the environment that allows her to escape from her own 
thoughts and to meditate. The seaside affords her and the others the opportunity to experience an inner peace.

...I think you breathe it all in and I think just getting away into sort of nothingness is very spiritual and it does help me an awful lot, you know just to sit quietly and almost meditate where you block everything out of your mind. [P.S.]

The seaside afforded the interviewees the opportunity to change the way they felt and to alter their state of mind; to experience expanded thought. The open spaces of the seaside offers nothingness and the chance just to be by the seaside without significant impingement from the contemporary man-made world or having to make continuous, conscious decisions. Preston-Whyte (2004) describes the coastline as a blank canvas for visitors and Rumsey (2010: 13) observes that visiting the seaside brings relief because, 'The sea marks the terminus of our control'. The environment allowed a certain clarity and depth of thought or encouraged a meditative state; interviewees made a connection between the sea and their consciousness. In most cases, this spirituality is best described as a sense of oneness, a potentially egoless state in which one feels connected to the world and which lies at the heart of spirituality, as discussed earlier (Heelas and Woodhead, 2005) . Interviewees felt a connection with the natural, vast and eternal. There is a connection between the immensity and limitlessness of the seafront and the depth of 'inner space within us all' (Bachelard, 1994: 206).

\section{Conclusion}

The experiences associated with the promenade, beach and sea-views were the most significant reasons for leisure visits to Morecambe. The interviewees suggested that it is only when we leave behind the distractions of modern life 
that our senses become fully attuned to the natural world and we start to appreciate it and feel an awareness. The visitors involved in this research travelled to Morecambe to stroll, gaze and experience the coast. Higher order motivations and reactions were present; these tended to be shaped by the presence of the seascape and its associated characteristics (Jarratt, 2015a). They considered the coast to be a particularly beautiful, awesome and thought provoking place; one with which they felt an emotional and spiritual connection. In other words, the interviewees suggested that spending time by the edge of the vast blue space of Morecambe Bay, which they associate with timelessness and nothingness, is awe inspiring and encourages modes of expanded thought - that is, to think more deeply than normal, to meditate, to be more self-aware and to experience spirituality. They consistently talked in very positive terms about connecting or re-connecting with the sea, nature or God. This timeless space is a blank canvas that allows visitors to take what they need from it - in a sense, the void fills a void (Bachelard, 1994; Gayton, 1996; Preston-Whyte, 2004). This offers a potential insight into spiritual elements of the touristic seaside experience and the visitor consumption of 'nature' or blue space.

Undoubtedly, some of the comments from interviewees could perhaps be described as clichéd, but this in itself can be considered part of a wider sociocultural construction which forms place identity and interpretation of landscape. Most of the comments relating to spirituality were carefully considered, strongly felt, clearly expressed and, in some cases, well justified. Some interviewees focussed more on spirituality than others, yet there was a consistent suggestion of a spiritual interpretation or, in some cases, a search for meaning (as discussed by Willson et al., 2013). Furthermore, spiritual experiences were seen as an important element of an uplifting seaside visit more generally. With 
this in mind, it could be argued that some aspects of what is referred to here as spirituality could also be accommodated into a discussion of seaside-related wellness (see Bell et al., 2015; White et al., 2013) and the well-established theories relating to the psychological benefits of natural spaces. There is without doubt a sizeable overlap but, nevertheless, the references made throughout the interviews to our place in the world, putting our own short lives into perspective, creation and God can clearly be accommodated in a discussion of spirituality and were described in these terms by interviewees. Other references, notably those regarding beauty of the environment or grand vistas, employed similar language and were in line with this discussion but were not consistently highlighted as 'spiritual' by interviewees. Yet they often preceded topics which were more clearly considered spiritual and can perhaps be placed on one end of a spiritual scale, as discussed by Hay and Nye (1996); they could certainly be accommodated by Schopenhauer's (2010) sliding scale between the beautiful and fully sublime.

It may seem unlikely that a visit to Morecambe, with its image problems and other challenges, may be thought of as a 'spiritual' experience. Nevertheless, the views across the bay, sitting on the beach and generally spending time by the seaside at Morecambe were seen by the interviewees in precisely these terms. In other words, 'spiritual' was not a word offered to describe the resort itself, but within the interviews this it was consistently volunteered as a description of the respondents' coastal experience in the resort. Indeed, the outcomes of this research suggest that similar experiences may occur amongst tourists in other resorts and coastal locations; that is, the research points to the possibility of a transferable seaside experience with spirituality at its core, distinguished by perceptions of timelessness and 
nothingness, rather than something place specific and bound only to a particular resort.

Nevertheless, it is acknowledged that this research explores the perspective of only particular group of cases; it cannot be necessarily assumed that the findings would be similar at another resort (perhaps especially a more developed resort with a wider range of man-made attractions), or indeed amongst another demographic. However, the research does offer the intriguing possibility that a stroll along the promenade allows for a heightened sense of spirituality which feeds into wider touristic enjoyment. This enjoyment and appreciation of the sea is reflected in a domestic and international leisure tourism industry which is dominated by coastal destinations.

Further research in this area may facilitate understanding of the experience of coastal tourism visits, not only from the perspective of tourism studies but also in terms of comprehending the scope of everyday secular spirituality which, for contemporary societies, may manifest itself through experiencing 'natural' environments and, in particular, the blue space offered by the coast. This search for meaning and spirituality in 'natural' places may be part of the aforementioned evolution of religious beliefs. Alternatively, this search may simply be a reaction to the secularisation of modern society, as reflected by the author Julian Barnes (2009: 1) who wrote, 'I don't believe in God, but I miss Him.' 


\section{References}

Aitchison, C., N. Macleod and S. Shaw (2002) Leisure and Tourism Landscapes: Social and Cultural Geographies. London: Routledge.

Allcock, J. (1988) 'Tourism as a Sacred Journey', Loisir et Société 11(1): 33-48.

Bachelard, G. (1994) The Poetics of Space. Boston, MA: Beacon Press. Barnes, J. (2009) Nothing to Be Frightened of. London: Vintage Books.

Bell, S., C. Phoenix, R. Lovell, et al. (2015) 'Seeking Everyday Wellbeing: The Coast as a Therapeutic Landscape', Social Science \& Medicine 142: 56-67.

Bingham, R. (1990) Lost Resort: The Flow and Ebb of Morecambe. Milnthorpe: Cicerone Press.

Brady, E. (2003) Aesthetics of the Natural Environment. Tuscaloosa, AL: University of Alabama Press.

Brierley, P. (1999) Religious Trends, 1998/99, No.1. London: Christian Research.

Brown, M. (1998) The Spiritual Tourist. London: Bloomsbury.

Bull, A. (2006) 'Is a Trip to the Seaside a Spiritual Journey? in Proceedings of Tourism: The Spiritual Dimension Conference', Lincoln University, Lincoln, 5-7 April.

Burls, A. (2007) 'People and Green Spaces: Promoting Public Health and Mental Well-Being through Ecotherapy', Journal of Public Mental Health 6(3): 24-39.

Carter, T. (2014) 'Wading through Mangroves: Thoughts on Theorizing the Coast', pp. 29-43 in P. Gilchrist, T. Carter and D. Burdsey (eds) Coastal Cultures: Liminality and Leisure. Eastbourne: Leisure Studies Association.

Centre for Social Justice (2013) 'Turning the Tide Social Justice in Five Seaside Towns'. Available at: 
http://www.centreforsocialjustice.org.uk/publications/turning-the-tide-socialjustice-infive-seaside-towns (accessed 29 July 2014).

Chapman, A. and D. Light (2014) 'Working with the Carnivalesque in Seaside Resorts: An Employee Perspective', Paper presented at the COaST Seascapes: The Cultural Life of Seaside Towns Conference, Turner Contemporary Gallery, Margate.

Corbin, A. (1994) The Lure of the Sea. Oxford: Blackwell.

Darker, C., M. Larkin and D. French (2007) 'An Exploration of Walking Behaviour: A nInterpretative Phenomenological Approach', Social Science \& Medicine 65(10): 2172-83.

Devereux, C. and E. Carnegie (2006) 'Pilgrimage: Journeying beyond Self', Tourism Recreation Research 31(1): 47-56.

Donaldson, C. (2014) 'Lancaster University Blog'. Available at: http://www.lancaster.ac.uk/news/

blogs/christopher-donaldson/over-sands-to-the-lakes/ (accessed 18 July 2014).

Driver, B., D. Dustin, T. Baltic et al. (eds) (1996) Nature and the Human Spirit: Toward an Expanded Land Management Ethic. State College, PA: Venture Publishing.

Durkheim, E. (2008) The Elementary Forms of Religious Life (trans. C. Cosman). Oxford: Oxford University Press.

Dyson, J., M. Cobb and D. Forman (1997) 'The Meaning of Spirituality: A Literature Review', Journal of Advanced Nursing 26(6): 1183-8.

Eliot, T. S. (1922) The Waste Land. New York: Horace Liveright.

Fisher, J., L. Francis and P. Johnson (2000) 'Assessing Spiritual Health via Four Domains of Spiritual Wellbeing: The SH4DI', Pastoral Psychology 49(2): 133-45.

Francis, L., E. Williams, J. Annis and M. Robbins (2008) Understanding Cathedral Visitors: Psychological Type and Individual Differences in Experience and Appreciation, Tourism Analysis 13(1): 71-80. 
Fredrickson, L. and D. Anderson (1999) 'A Qualitative Exploration of the Wilderness Experience as a Source of Spiritual Inspiration', Journal of Environmental Psychology 19(1): 21-9.

Gale, T. (2005) 'Modernism, Post-Modernism and the Decline of British Holiday Destinations: A Case Study of Rhyl, North Wales', Tourism Geographies 7(1): 86-112.

Gayton, D. (1996) Landscapes of the Interior: Re-Explorations of Nature and the Human Spirit. Gabriola Island, BC, Canada: New Society Publishers.

Gibson, I., C. Crawford and Geddes (2008) 'England's Northwest Staying Visitor Survey 2007-8'. Available at:

http://www.lancashireandblackpool.com/xsdbimgs/Microsoft\%20Word\%20 -\%20Final\%20Report\%20NW\%20Staying\%20Visitors.pdf

Gilchrist, P., T. Carter and D. Burdsey (2014) 'Costal Cultures: Liminality and Leisure', pp. 95-115 in P. Gilchrist, T. Carter and D. Burdsey (eds) Coastal Cultures: Liminality and Leisure. Eastbourne: Leisure Studies Association.

Graburn, N. (1989) 'Tourism: The Sacred Journey', pp. 21-36 in V. Smith (ed.) Hostsand Guests: The Anthropology of Tourism, 2nd edn. Philadelphia, PA: University of Pennsylvania Press.

Gratton, C. and I. Jones (2004) Research Methods for Sport Studies. London: Routledge.

Harvey, D. (2003) 'Cell Church: Its Situation in British Evangelical Culture', Journal of Contemporary Religion 18(1): 95-109.

Hartig, T., R. Mitchell, S. De Vries and H. Frumkin (2014) Nature and Health, Annual Review of Public Health 35: 207-228.

Hassan, J. (2003) The Seaside, Health and the Environment in England and Wales since 1800. Aldershot: Ashgate.

Hay, D. and P. Socha (2005) 'Science Looks at Spirituality - Spirituality as a Natural Phenomenon: Bringing Biological and Psychological Perspectives Together', Zygon 40(3): 589-612. 
Hay, D. and R. Nye (1996) 'Investigating Children's Spirituality: The Need for a Fruitful Hypothesis', International Journal of Children's Spirituality 1(1): 6-16.

Heelas, P. (1998) 'Introduction: On Differentiation and Dedifferentiation', pp. 118 in P. Heelas, D. Martin and P. Morris (eds) Religion, Modernity and Postmodernity. Oxford: Blackwell.

Heelas, P. and L. Woodhead (2005) The Spiritual Revolution: Why Religion Is Giving Way to Spirituality. Oxford: Blackwell.

Heintzman, P. (2010) 'Nature-Based Recreation and Spirituality: A Complex Relationship', Leisure Sciences 32(1): 72-89.

Hern, A. (1967) The Seaside Holiday: The History of the English Seaside Resort. London: The Cresset Press.

Houtman, D. and S. Aupers (2007) 'The Spiritual Turn and the Decline of Tradition: The Spread of Post-Christian Spirituality in 14 Western Countries, 1981-2000', Journal for the Scientific Study of Religion 46(3): 305-20.

Jarratt, D. (2015a) 'Seasideness: A Sense of Place and Space at a British Seaside Resort', pp. 147-64 in S. Elkington and S. Gammon (eds) Landscapes of Leisure: Space, Place and Identities. Basingstoke: Palgrave Macmillan.

Jarratt, D. (2015b) 'Sense of Place at a British Coastal Resort: Exploring "Seasideness" in Morecambe', Tourism: An International Interdisciplinary Journal 63(3): 351-63.

Jepson, D. and R. Sharpley (2015) 'Exploring the Emotional Dimension of Rural Tourism Experiences', Journal of Sustainable Tourism 23(8-9): 1157-78.

Jordison (2012) 'Back to the Scene of the Grime: The Man Behind Crap Towns Revisits Morecambe', The Independent, 9 June. Available at: http://www.independent.co.uk/news/uk/this-britain/back-to-the-scene-of-thegrime-the-man-behind-crap-towns-revisits-

morecambe7820913.html?action=gallery $\&$;ino $=1$

Kale, S. (2004) 'Spirituality, Religion, and Globalization', Journal of Macromarketing 24(2): 92-107. 
Kaplan, S. (1995) 'The Restorative Benefits of Nature: Towards an Integrative Framework', Journal of Environmental Psychology 15(3): 169-82.

Korpela, K. and T. Hartig (1996) 'Restorative Qualities of Favourite Places', Journal of Environmental Psychology 16(3): 221-33.

Lambert, Y. (2004) 'A Turning Point in Religious Evolution in Europe', Journal of Contemporary Religion 19(1): 29-45.

Lancaster City Council (2011) 'Morecambe STEAM Report 2010'. Available at: http://www.lancaster.gov.uk/tourism/destination-performance/ (accessed 17 November 2012).

Lencek, L. and G. Bosker (1998) The Beach: The History of Paradise on Earth. New York: Viking.

MacCannell, D. (1976) The Tourist: A New Theory of the Leisure Class. New York: Schocken Books.

Montes, S. (1996) Use of Natural Settings to Promote, Maintain and Restore Human Healt, pp.105-24 in B. Driver, D. Dustin, T. Baltic, G. Elsner and G. Peterson (eds), Nature and theHuman Spirit: Toward an Expanded Land Management Ethic. State College, PA: Ventura Publishing.

Miner-Williams, D. (2006) 'Putting a Puzzle Together: Making Spirituality Meaningful for Nursing using an Evolving Theoretical Framework', Journal of Clinical Nursing 15(7): 811-21.

Nicholson, N. (1995) The Lakers: The Adventures of the First Tourists. Milnthorpre, Cumbria: Cicerone Press.

Olsen, D. (2006) 'Typologies of Spiritual Tourists'. Unpublished paper presented at Tourism: The Spiritual Dimension Conference, University of Lincoln, Lincoln, 5-7 April.

Pargament, K. (1999) 'The Psychology of Religion and Spirituality? Yes and No', International Journal for the Psychology of Religion 9(1): 3-16.

Pimlott, J. (1947) The Englishman's Holiday. London: Faber \& Faber. 
Preston-Whyte, R. (2004) 'The Beach as a Liminal Space', pp. 349-59 in A. Lew, C. M. Hall and A. Williams (eds) A Companion to Tourism. Oxford: Blackwell.

Rinschede, G. (1992) 'Forms of Religious Tourism', Annals of Tourism Research 19(1): 51-67.

Rumsey, A. (2010) Strangely Warmed: Reflections on God, Life and Bric-aBrac. London:Continuum Books.

Schopenhauer, A. (2010) The World as Will and Representation, vol. 1. Cambridge: Cambridge University Press.

Sharpley, R. (2009) 'Tourism, Religion and Spirituality', pp. 237-53 in M. Jamal and T. Robinson(eds) The Sage Handbook of Tourism Studies. London: SAGE.

Sharpley, R. and D. Jepson (2011) Rural Tourism: A Spiritual Experience? Annals of Tourism Research 38(1): 52-71.

Sharpley, R. and P. Sundaram (2005) 'Tourism: A Sacred Journey? The Case of Ashram Tourism, India', International Journal of Tourism Research 7(3): 16171.

Shaw, G. and A. Williams (eds) (1997) The Rise and Fall of British Coastal Resorts: Cultural and Economic Perspectives. London: Pinter.

Shields, R. (1991) Places on the Margin: Alternative Geographies of Modernity. Abingdon: Routledge.

Smith, M. (2003) 'Holistic Holidays: Tourism and the Reconciliation of Body, Mind and Spirit', Tourism Recreation Research 28(1): 103-8.

Smith, J. A., P. Flowers, and M. Larkin (2009) Interpretative Phenomenological Analysis: Theory Method and Research. London: SAGE.

Stark, R., E. Hamberg and A. Miller (2005) 'Exploring Spirituality and Unchurched Religions in America, Sweden and Japan', Journal of Contemporary Religion 20(1): 3-23. 
Steiner, C. and Y. Reisinger (2006) 'Ringing the Fourfold: A Philosophical Framework for Thinking about Wellness Tourism', Tourism Recreation Research 31(1): 5-14.

Theos (2013) The Spirit of Things Unseen: Belief in Post-Religious Britain. London: Theos.

Timothy, D. and D. Olsen (eds) (2006) Tourism, Religion and Spiritual Journeys. Abingdon: Routledge.

Trotman, J. (2007, unpublished) 'Morecambe: Tourism Trends and Redevelopment', Briefing Report, Lancaster City Council.

Tunstall, S. and E. Penning-Rowsell (1998) 'The English Beach: Experiences and Values', The Geographical Journal 164(3): 319-32.

Urry, J. (1997) 'Cultural Change and the Seaside Resort', pp. 102-17 in G. Shaw and A. Williams (eds) The Rise and Fall of British Coastal Resorts: Cultural and Economic Perspectives. London: Mansell.

Urry, J. and J. Larsen (2011) The Tourist Gaze (3.0). London: SAGE. Visit England (2013) 'The GB Day Visit: Statistic 2013'. Available at: https://www.visitbritain.org/gb-day-visits-survey-archive (accessed 28 July 2014).

Völker, S. and T. Kistemann (2011) 'The Impact of Blue Space on Human Health and Well-Being - Salutogenetic Health Effects of Inland Surface Waters: A Review', International Journal of Hygiene and Environmental Health 214(6): 449-60.

Vukonić, B. (1996) Tourism and Religion. Oxford: Pergamon.

Walton, J.K. (1983) The English Seaside Resort: A Social History 1750-1914. Leicester: Leicester University Press.

Walton, J.K. (2000) The British Seaside: Holidays and Resorts in the Twentieth Century. Manchester: Manchester University Press.

Walvin, J. (1978) Beside the Seaside. London: Allen Lane. 
Webb, D. (2005) 'Bakhtin at the Seaside: Utopia, Modernity and the Carnivalesque', Theory Culture \& Society 22(3): 121-38.

White, M., A. Smith, K. Humphryes, et al. (2010) 'Blue Space: The Importance of Water for Preference, Affect, and Restorativeness Ratings of Natural and Built Scenes', Journal of Environmental Psychology 30(4): 482-93.

White, M., S. Pahl, K. Ashbullby, et al. (2013) 'Feelings of Restoration from Recent Nature Visits', Journal of Environmental Psychology 35(1): 40-51.

Willson, G., A. McIntosh and A. Zahra (2013) 'Tourism and Spirituality: A Phenomenological Analysis', Annals of Tourism Research 42(1): 150-68.

Wuthnow, R. (1998) After Heaven: Spirituality in America since the 1950s. Berkeley, CA:University of California Press.

Zinnbauer, B., K. Pargament and A. Scott (1999) 'The Emerging Meanings of Religiousness and Spirituality: Problems and Prospects', Journal of Personality 67(6): 889-919.

David Jarratt $(\mathrm{PhD})$ is a Senior Lecturer in The School of Management at the University of Central Lancashire, Preston. His research interests include the consumption of tourism, sense of place and coastal tourism. He teaches on International Tourism and Event Management courses.

Richard Sharpley is Professor of Tourism and Development at the University of Central Lancashire. His research interests include the consumption of tourism, in particular the spiritual dimensions of the tourist experience. 